\title{
Leukaemia clusters in Great Britain. 1. Space-time interactions
}

\author{
E G Knox, Estelle Gilman
}

\begin{abstract}
Study objective-The aim was to test a large set of childhood leukaemia and lymphoma registrations for the presence of clusters in space and in time.

Design-The study was a space-time cluster analysis.

Setting-England, Wales and Scotland.

Patients-All registrations for leukaemia and lymphoma between 1966 and 1983 in children aged 0 to 14 years were examined. The records included date and age of registration, sex, diagnosis, and the map reference of the postcode of residence. Of the 9411 registrations, 8888 were suitable for inclusion.

Main results-There was a statistically significant excess of case pairs occurring jointly within $0.5 \mathrm{~km}$ and $60 \mathrm{~d}$ of each other: 68 pairs compared with $50 \cdot 0$ expected. The excess was detectable in central England, in the north of England and Scotland, but not in the south west of England. It was concentrated within the age band 4 to 7 years and among the lymphatic leukaemias. Several potential artefacts were considered and excluded, but the possibility remained that clustered detections might be triggered by haematological examinations undertaken for some communicable disease.

Conclusions-There was strong evidence of joint spatial-temporal clustering, with an excess of pairs separated by very short time and distance intervals. The causes are probably biological rather than artefactual, but further work will be necessary in order to exclude the latter.
\end{abstract}

f Epidemiol Community Health 1992; 46: 566-572

We recently reported clustering among childhood leukaemias and lymphomas in Great Britain. ${ }^{1}$ The clusters occurred jointly in space and in time, as judged by the dates and the addresses at registration. The full database consisted of all registrations (9411) of leukaemias and of nonHodgkin's lymphomas in children aged 0-14 years in England, Wales, and Scotland between 1966 and 1983. The analysis itself was based upon a subset with the most accurately recorded dates and times. More pairs of registrations occurred jointly in the same calendar month and within a short distance of each other than should occur by chance. The cluster pattern was present in several different diagnostic subsets. It was also present among pairs spanning different diagnoses and different age groups. Space-time interaction in leukaemia had been described before ${ }^{2-6}$ but never on the basis of so large a data set, assembled and validated to a uniform standard, and free of suspicion that the material was tested because clustering had already been recognised within it.

Here, we report a more detailed analysis. We address four specific questions. First, could the clustering be an artefact of the registration process? It is unlikely with these diseases, and with a high grade registration system, ${ }^{7}$ that it could represent time limited patches of overdiagnosis or of varied ascertainment level. However, one case might precipitate the registration of another close by, which had previously been overlooked. Second, could the clustering be an artefact arising from temporal-spatial instability of the population itself? If the density pattern of a population should drift, then any events arising within the population will reflect that changing pattern. Third, we must ask whether the interaction is statistically primary, genuinely dependent upon the dates and places of registration, or whether it is statistically secondary to an interaction based upon another date and place (of birth, say), the temporalspatial coordinates of which are correlated with those of registration. Fourth, we must ask what biological models-including infective or toxic or radiation exposures-are compatible with the temporal-spatial patterns described.

\section{Methods}

THE DATA

The origins, the preparation, the validation, and the detailed contents of the data set are fully described elsewhere. ${ }^{7}$ It consisted of 9411 registrations of leukaemias and non-Hodgkin's lymphomas in children aged 0-14 years, in England, Wales, and Scotland, between 1966 and 1983. This national registration file was abridged and consolidated before presentation to research groups in order to preserve confidentiality. Each abridged registration record comprised a unique index number, the sex of the child, the ICDO coded type and site of the neoplasm, the "anniversary date" (day, month, year), the age at anniversary- 0 in completed months, the census tract and the enumeration district codes, and a map reference indicating the position of the postcode. Anniversary- 0 is the date on which the diagnosis was made and treatment begun.

The postcode coordinates recorded in the file had been obtained initially from the Central Postcode Directory. The Directory records its postcode map references to a resolution of 100 metres, or 10 metres in Scotland. They relate to the first address within the postcode. These map references were then checked, corrected, and supplemented-where this was necessary and possible-against a current commercial index of 
postcode centroids, supplied by Pinpoint Analysis Ltd. The map references finally entered to the consolidated/abridged research file were recorded as seven digit eastings and seven digit northings, formally correct to one metre. However, many of them-those not cross checked against the Pinpoint index-were still in practical terms recorded only to a resolution of 100 metres. For this and for other reasons-to which we return later-the actual resolutions of these values are to a degree uncertain. However, the case records contained indicators of the origins of the addresses, and of the presumed reliability of the allocated postcodes and coordinates, and this enabled us to exclude from analysis those of known doubtful validity.

The relationships between these first address and centroid coordinates, and the actual addresses within the postcodes, are also uncertain; but a published analysis claims ${ }^{8}$ that over $50^{\circ}{ }_{0}$ of the coordinates are accurate to within 100 metres, and $90 \%$ to within 400 metres. There are about 17 addresses per postcode, so that most individual addresses would then be represented to an accuracy of about 200 metres. Address separations less than this will generally have identical coordinates; although some will not; and some with wider separations will. We shall pursue the issue of resolution at a later stage.

The date of diagnosis/registration was also sometimes uncertain and substitute dates had sometimes been entered. Again, however, the record contained an indicator of reliability, and doubtful dates were excluded from analysis. Using these reliability indicators we prepared a subfile which excluded all those dates and places the inaccuracy of which might invalidate our conclusions. Diagnoses were then blocked into three main groups comprising (a) lymphocytic and unspecified leukaemias (ICD 980.0-980.4, $982 \cdot 0-982 \cdot 5,985 \cdot 0$ ), (b) myeloid leukaemias (ICD $984 \cdot 0-984.9,985 \cdot 1-994 \cdot 0$ ), and (c) the nonHodgkin's lymphomas together with the unspecified lymphomas (ICD 951/1-975.0). A number of other diagnoses-for example specified leukaemias and lymphomas not falling within these groups-were excluded. This resulted in a reduced file of 8889 registrations.

Dates of registration were converted to "day of 20th century", and approximate dates of birth were calculated by subtracting "age in completed months at registration". Clearly, these estimated dates of birth have an error of about plus or minus 15 days. Nevertheless, this procedure allowed us to identify a pair of like sexed concordant twins with the same type of leukaemia and the same map position, both registered during the first year of life. We excluded one of the pair, treating the other as a single case, thus leaving 8888 events for analysis.

\section{ANALYSIS}

The standard methods for the detection of spacetime interactions are based upon an examination of all possible pairs. There are $n(n-1) / 2$ possible pairs from $\mathrm{n}$ events; for example there are 39493828 pairs from among the 8888 events. This permits a tabulation of distance separations against time separations, to see whether there is a disproportionate excess of pairs combining short distances with short time intervals.

For a dataset which extended over 18 years and over $1000 \mathrm{~km}$, the question arises whether a false interaction might be generated through movements in the density pattern of the population at risk. We took precautions against such mis-
Table I Spatialtemporal distribution of pairs of leukaemias registered within 1000 days and $100 \mathrm{~km}$ of each other. Registrations of leukaemias and lymphomas ( 8888 cases)

\begin{tabular}{|c|c|c|c|c|c|c|c|c|}
\hline \multirow{2}{*}{$\begin{array}{l}\text { Time } \\
\text { separation } \\
\text { (days) }\end{array}$} & \multicolumn{6}{|c|}{ Distance separation $(\mathrm{km})$} & \multirow{2}{*}{$20 \cdot 0-100 \cdot 0$} & \multirow[b]{2}{*}{$0-100 \cdot 0$} \\
\hline & $0-0.5$ & $0 \cdot 5-1 \cdot 0$ & $1 \cdot 0-1 \cdot 5$ & $1 \cdot 5-2 \cdot 0$ & $2 \cdot 0-5 \cdot 0$ & $5 \cdot 0-20 \cdot 0$ & & \\
\hline \multicolumn{9}{|l|}{$0-15$} \\
\hline Observed & 22 & 23 & 43 & 36 & 385 & 3867 & 32031 & 36407 \\
\hline Expected & 12.99 & $24 \cdot 26$ & $31 \cdot 44$ & $40 \cdot 10$ & $380 \cdot 78$ & $3915 \cdot 26$ & $32002 \cdot 17$ & - \\
\hline $\mathrm{O} / \mathrm{E}$ & $\begin{array}{l}1.69 \\
0.09\end{array}$ & 0.95 & 1.37 & 0.90 & 1.01 & 0.99 & 1.00 & - \\
\hline $\mathrm{p}$ & 0.014 & - & 0.029 & - & - & - & - & - \\
\hline \multicolumn{9}{|l|}{$16-30$} \\
\hline Observed & & 25 & 27 & 43 & 332 & 3735 & 30548 & 34723 \\
\hline Expected & $12 \cdot 40$ & $23 \cdot 73$ & 29.98 & $38 \cdot 24$ & $363 \cdot 16$ & $3734 \cdot 17$ & 30521.91 & \\
\hline $\mathrm{O} / \mathrm{E}$ & 1.05 & 1.05 & 0.90 & $1 \cdot 12$ & 0.91 & $1 \cdot 00$ & 1.00 & - \\
\hline $\mathrm{p}$ & 0.061 & - & - & 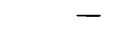 & - & - & - & - \\
\hline \multicolumn{9}{|l|}{$31-60$} \\
\hline Observed & 33 & 46 & 53 & 60 & 691 & 7496 & 60590 & 68969 \\
\hline Expected & $24 \cdot 62$ & 45.94 & 59.55 & 75.96 & $721 \cdot 34$ & 7417.03 & $60624 \cdot 54$ & - \\
\hline $\mathrm{O} / \mathrm{E}$ & 1.34 & 1.00 & 0.89 & 0.79 & 0.96 & 1.01 & 1.00 & - \\
\hline $\mathrm{p}$ & & - & - & - & - & - & - & - \\
\hline \multicolumn{9}{|l|}{$61-120$} \\
\hline Observed & 48 & 102 & 125 & 148 & 1489 & 14854 & 121844 & 138610 \\
\hline $\begin{array}{l}\text { Expected } \\
\mathrm{O} / \mathrm{E}\end{array}$ & $49 \cdot 47$ & $92 \cdot 35$ & $119 \cdot 69$ & 152.67 & 1449.71 & 14906.03 & $121839 \cdot 78$ & \\
\hline $\begin{array}{l}\mathrm{O} / \mathrm{E} \\
\mathrm{p}\end{array}$ & 0.97 & $1 \cdot 10$ & 1.04 & 0.97 & 1.03 & 1.00 & $1 \cdot 00$ & - \\
\hline $\mathbf{p}$ & - & - & - & & - & - & - & - \\
\hline \multicolumn{9}{|l|}{$121-365$} \\
\hline $\begin{array}{l}\text { Observed } \\
\text { Expected }\end{array}$ & & & & & 5758 & 59697 & 487043 & 554111 \\
\hline $\begin{array}{l}\text { Expected } \\
\mathrm{O} / \mathrm{E}\end{array}$ & $\begin{array}{r}197.78 \\
0.02\end{array}$ & $369 \cdot 18$ & $\begin{array}{r}478.47 \\
0.96\end{array}$ & $610 \cdot 32$ & 5795.39 & 59589.91 & $487069 \cdot 94$ & - \\
\hline $\mathrm{p}$ & & 0.93 & $\stackrel{0.96}{-}$ & $1 \cdot 03$ & 0.99 & $1 \cdot 00$ & 1.00 & - \\
\hline \multicolumn{9}{|l|}{$366-1000$} \\
\hline Observed & & & 1180 & & 14201 & & 1188861 & 1352495 \\
\hline Expected & $482 \cdot 74$ & $901 \cdot 12$ & 1167.87 & $1489 \cdot 70$ & 14145.62 & $145449 \cdot 30$ & 1188858.65 & - \\
\hline $\mathrm{O} / \mathrm{E}$ & $1 \cdot 00$ & 1.02 & 1.01 & 1.00 & 1.00 & 1.00 & $\begin{array}{l}0.00 \\
0\end{array}$ & \\
\hline Total & & & & & & & & \\
\hline & 780 & 1456 & 1887 & 2407 & 22856 & 235012 & 1920917 & 2185315 \\
\hline
\end{tabular}


interpretation in our previous paper ${ }^{1}$ by examining the material in three separate time periods. However there was still a danger that major movements of population might have taken place within one or more of these intervals; so in the present analysis we have adopted another and more restrictive approach. The events were sorted in ascending date order, and the material was then examined for interactions within a moving time window of arbitrary length-usually 1000 days. Technically, each case was paired with every subsequent case within this upper limit. This approach has the dual advantage of greatly reducing the numbers of non-informative pairs examined, while limiting even further the scope for detecting and misinterpreting major population drifts. Its only disadvantage is that it effectively limits the examination to detecting geographical movements which occur within this time. We also restricted the geographical scope of the interaction search, usually to within $100 \mathrm{~km}$.

We also made use of further novel techniques. One was a modification to the "all possible pairs" technique in which the distances between pairs were standardised for the local density of events. This was carried out using a modification of a method described and used elsewhere. ${ }^{9}$ Each record was examined to see how many other cases were located within a nominated distance, and the number (plus 1) stored as a "proximity count" within the registration record. Different nominated distances-typically $4 \mathrm{~km}$-were used in different runs. These individual proximity counts were later divided by the overall mean proximity count, the ratio then providing a crude indicator of the density of other registrations in the immediate vicinity of the index case. In the subsequent analysis of pairs, each of the geographical separations was then stretched or shrunk according to the local density indices associated with the two registrations. Technically, the measured distance was multiplied by the harmonic mean of the two density ratios. The general intention was to provide a transformed index of distance scaled in terms of the numbers of intermediate personal contacts, rather than the number of metres.

The second novel technique was an elaboration of the examination based upon pairs. We sought space-time interaction among triplets of cases. In practice we used a subset of all possible triplets of events- $n(n-1)(n-2) / 6$ from $n$ events: in this case, approximately $1.1698 \times 10^{11}$. This required an extension of the notions of "distance apart" and "time apart", beyond the usages appropriate to pairs. A triplet "distance" was defined as the mean of the three distances between the three cases: one third of the perimeter of the triangle. Time intervals were defined as the interval between the first and the last of the three events. An analysis conducted on a date sorted file, within moving limits of 400 days and $100 \mathrm{~km}$, generated 32400050 triplets, approximately $0.028 \%$ of all possible triplets. This method, including extensions to quadruplets and higher n-tuplets, has also been described and used in other contexts. ${ }^{9}$

\section{Results}

\section{BASIC INTERACTIONS}

Table I gives the numbers of pairs observed within different distance intervals and time intervals, among all those pairs occurring within a sliding time window of 1000 days; and within 100 $\mathrm{km}$ of each other. Each cell of the table records the observed number of pairs (0), the expected number of pairs $(E)$, the observed/expected ratio $(\mathrm{O} / \mathrm{E})$, and the $\mathrm{p}$ value, where it is significant. The $\mathrm{p}$ values were based upon $\chi^{2}$ testing where the numbers were large, but usually upon directly calculated single tailed Poisson probabilities. Table II provides the same material in cumulative form. Table III provides cumulative data for the same map locations but using estimated date of birth instead of registration.

There was a significant excess of pairs within 15 days and within $0.5 \mathrm{~km}$ of each other at the time of registration. Significant cumulative excesses also extended into time intervals beyond those likely to correspond with short term anticipation of diagnosis-that is, resulting from the local stimulus of one case leading to the recognition or registration of another. Also, there was no evidence of the later compensatory depletion of other short range, short time secondary registrations which such anticipatory diagnoses would then have caused. The examination of dates of birth
Table II Cumulative spatial-temporal distribution of pairs registered within 1000 days and 100 $\mathrm{km}$ of each other. Registrations of leukaemias and lymphomas (8888 cases)

\begin{tabular}{|c|c|c|c|c|c|c|c|c|}
\hline \multirow{2}{*}{\multicolumn{2}{|c|}{$\begin{array}{l}\text { Time } \\
\text { separation } \\
\text { (days) }\end{array}$}} & \multicolumn{7}{|c|}{ Distance separation $(\mathrm{km})$} \\
\hline & & \multirow{2}{*}{$\begin{array}{c}0-0.5 \\
22 \\
12.99 \\
1.69 \\
0.014\end{array}$} & \multirow{2}{*}{$\begin{array}{c}0-1 \cdot 0 \\
45 \\
37 \cdot 25 \\
1.21 \\
0.119\end{array}$} & \multirow{2}{*}{$\begin{array}{c}0-1 \cdot 5 \\
88 \\
68 \cdot 69 \\
1.28 \\
0.014\end{array}$} & \multirow{2}{*}{$\begin{array}{r}0-2 \cdot 0 \\
124 \\
108 \cdot 79 \\
1 \cdot 14 \\
-\end{array}$} & \multirow{2}{*}{$\begin{array}{c}0-5 \cdot 0 \\
509 \\
489.57 \\
1.04 \\
-\end{array}$} & \multirow{2}{*}{$\begin{array}{r}0-20 \cdot 0 \\
4376 \\
4404 \cdot 83 \\
0.99 \\
-\end{array}$} & \multirow{2}{*}{$\begin{array}{r}0-100 \cdot 0 \\
36407 \\
= \\
-\end{array}$} \\
\hline $0-15$ & $\begin{array}{l}\text { Observed } \\
\text { Expected } \\
\mathrm{O} / \mathrm{E} \\
\mathrm{p}\end{array}$ & & & & & & & \\
\hline $0-30$ & $\begin{array}{l}\text { Observed } \\
\text { Expected } \\
\mathrm{O} / \mathrm{E} \\
\mathrm{p}\end{array}$ & $\begin{array}{l}35 \\
25 \cdot 39 \\
1 \cdot 38 \\
0.041\end{array}$ & $\begin{array}{l}83 \\
72 \cdot 78 \\
1 \cdot 14\end{array}$ & $\begin{array}{r}153 \\
134.20 \\
1.14 \\
\end{array}$ & $\begin{array}{r}232 \\
212.55 \\
1.09 \\
-\end{array}$ & $\begin{array}{r}949 \\
956.49 \\
1.99 \\
-\end{array}$ & $\begin{array}{r}8551 \\
8605.91 \\
0.99 \\
-\end{array}$ & $\begin{array}{r}71130 \\
=\end{array}$ \\
\hline $0-60$ & $\begin{array}{l}\text { Observed } \\
\text { Expected } \\
\mathrm{O} / \mathrm{E} \\
\mathrm{p}\end{array}$ & $\begin{array}{l}68 \\
50 \cdot 01 \\
1.36 \\
0.009\end{array}$ & $\begin{array}{l}162 \\
143 \cdot 35 \\
1 \cdot 13\end{array}$ & $\begin{array}{l}285 \\
264 \cdot 32 \\
1 \cdot 08\end{array}$ & $\begin{array}{r}424 \\
418 \cdot 63 \\
1.01 \\
-\end{array}$ & $\begin{array}{r}1832 \\
1883.92 \\
0.97 \\
-\end{array}$ & $\begin{array}{r}16930 \\
16950 \cdot 37 \\
1.00 \\
-\end{array}$ & $\begin{array}{r}140099 \\
= \\
-\end{array}$ \\
\hline $0-120$ & $\begin{array}{l}\text { Observed } \\
\text { Expected } \\
\mathrm{O} / \mathrm{E} \\
\mathrm{p}\end{array}$ & $\begin{array}{c}116 \\
99 \cdot 48 \\
1.17 \\
0.057\end{array}$ & $\begin{array}{r}312 \\
285 \cdot 17 \\
1.09 \\
-\end{array}$ & $\begin{array}{l}560 \\
525.84 \\
1.06\end{array}$ & $\begin{array}{r}847 \\
832.82 \\
1.02 \\
-\end{array}$ & $\begin{array}{r}3744 \\
3747.81 \\
1.00 \\
-\end{array}$ & $\begin{array}{r}33696 \\
33720.59 \\
1.00 \\
-\end{array}$ & $\begin{array}{r}278709 \\
=\end{array}$ \\
\hline $0-365$ & $\begin{array}{l}\text { Observed } \\
\text { Expected } \\
\mathrm{O} / \mathrm{E} \\
\mathrm{p}\end{array}$ & $\begin{array}{r}298 \\
297.26 \\
1.00 \\
-\end{array}$ & $\begin{array}{r}836 \\
852 \cdot 14 \\
0.98 \\
-\end{array}$ & $\begin{array}{r}1543 \\
1571.27 \\
0.98 \\
-\end{array}$ & $\begin{array}{r}2460 \\
2488.57 \\
0.99 \\
-\end{array}$ & $\begin{array}{r}11115 \\
11198.96 \\
0.99 \\
-\end{array}$ & $\begin{array}{r}100764 \\
100761.65 \\
1.00 \\
-\end{array}$ & $\begin{array}{r}832820 \\
\text { 二 }\end{array}$ \\
\hline \multicolumn{2}{|c|}{$0-1000$} & 780 & 2236 & 4123 & 6530 & 29386 & 264398 & 2185315 \\
\hline
\end{tabular}

$\mathrm{O} / \mathrm{E}=$ ratio of observed to expected registrations. Only significant $\mathrm{p}$ values are shown. 
Table III Cumulative spatial-temporal distribution of pairs born within 1000 days and 100 $\mathrm{km}$ of each other. Birth dates of leukaemias and lymphomas

\begin{tabular}{|c|c|c|c|c|c|c|c|c|}
\hline \multirow{2}{*}{\multicolumn{2}{|c|}{$\begin{array}{l}\text { Time } \\
\text { separation } \\
\text { (days) }\end{array}$}} & \multicolumn{7}{|c|}{$\underline{\text { Distance separation }(\mathrm{km})}$} \\
\hline & & \multirow{2}{*}{$\begin{array}{c}0-0.5 \\
11 \\
9.94 \\
1.11 \\
-\end{array}$} & \multirow{2}{*}{$\begin{array}{c}0-1 \cdot 0 \\
30 \\
27.60 \\
1.09 \\
-\end{array}$} & \multirow{2}{*}{$\begin{array}{r}0-1 \cdot 5 \\
60 \\
51 \cdot 73 \\
1 \cdot 16 \\
-\end{array}$} & \multirow{2}{*}{$\begin{array}{c}0-2 \cdot 0 \\
90 \\
82.62 \\
1.09 \\
-\end{array}$} & \multirow{2}{*}{$\begin{array}{l}0-5 \cdot 0 \\
414 \\
374 \cdot 62 \\
1 \cdot 11 \\
0.024\end{array}$} & \multirow{2}{*}{$\begin{array}{r}0-20 \cdot 0 \\
3456 \\
3406 \cdot 31 \\
1.01 \\
-\end{array}$} & \multirow{2}{*}{$\begin{array}{r}0-100 \cdot 0 \\
28102 \\
=\end{array}$} \\
\hline$\overline{0-15}$ & $\begin{array}{l}\text { Observed } \\
\text { Expected } \\
\mathrm{O} / \mathrm{E} \\
\mathrm{p}\end{array}$ & & & & & & & \\
\hline $0-30$ & $\begin{array}{l}\text { Observed } \\
\text { Expected } \\
\mathrm{O} / \mathrm{E} \\
\mathrm{p}\end{array}$ & $\begin{array}{l}23 \\
19 \cdot 67 \\
1 \cdot 17 \\
-\end{array}$ & $\begin{array}{l}67 \\
54 \cdot 61 \\
1 \cdot 23 \\
-\end{array}$ & $\begin{array}{r}121 \\
102 \cdot 36 \\
1 \cdot 18 \\
-\end{array}$ & $\begin{array}{c}191 \\
163 \cdot 48 \\
1 \cdot 17 \\
0.019\end{array}$ & $\begin{array}{l}804 \\
741 \cdot 26 \\
1.08 \\
0.012\end{array}$ & $\begin{array}{l}6874 \\
6740 \cdot 14 \\
1.02 \\
-\end{array}$ & $\begin{array}{r}55606 \\
=\end{array}$ \\
\hline $0-60$ & $\begin{array}{l}\text { Observed } \\
\text { Expected } \\
\mathrm{O} / \mathrm{E} \\
\mathrm{p}\end{array}$ & $\begin{array}{l}47 \\
38.88 \\
1 \cdot 21\end{array}$ & $\begin{array}{r}121 \\
107.95 \\
1 \cdot 12\end{array}$ & $\begin{array}{r}222 \\
202 \cdot 35 \\
1 \cdot 10 \\
-\end{array}$ & $\begin{array}{l}346 \\
323 \cdot 17 \\
1 \cdot 07 \\
-\end{array}$ & $\begin{array}{r}1479 \\
1465.35 \\
1.01 \\
-\end{array}$ & $\begin{array}{r}13296 \\
13324.04 \\
1.00 \\
\quad-\end{array}$ & $\begin{array}{r}109923 \\
\text { - }\end{array}$ \\
\hline $0-120$ & $\begin{array}{l}\text { Observed } \\
\text { Expected } \\
\mathrm{O} / \mathbf{E} \\
\mathrm{p}\end{array}$ & $\begin{array}{l}95 \\
77 \cdot 23 \\
1 \cdot 23 \\
0.028\end{array}$ & $\begin{array}{l}238 \\
214 \cdot 43 \\
1 \cdot 11\end{array}$ & $\begin{array}{l}429 \\
401.93 \\
1.07\end{array}$ & $\begin{array}{l}680 \\
641.93 \\
1.06\end{array}$ & $\begin{array}{l}2957 \\
2910.91 \\
1.02\end{array}$ & $\begin{array}{r}26628 \\
26465.91 \\
1.01\end{array}$ & $\begin{array}{r}218343 \\
\text { 二 }\end{array}$ \\
\hline $0-365$ & $\begin{array}{l}\text { Observed } \\
\text { Expected } \\
\text { O/E }\end{array}$ & $\begin{array}{r}249 \\
233 \cdot 79 \\
1 \cdot 07\end{array}$ & $\begin{array}{r}657 \\
649 \cdot 14 \\
1.01\end{array}$ & $\begin{array}{r}1188 \\
1216.77 \\
0.98\end{array}$ & $\begin{array}{r}1921 \\
1943.35 \\
0.99\end{array}$ & $\begin{array}{l}8730 \\
8811.57 \\
0.99\end{array}$ & $\begin{array}{r}80072 \\
80121.48 \\
1.00\end{array}$ & 661020 \\
\hline $0-1000$ & & 631 & 1752 & 3284 & 5245 & 23782 & 216244 & 1784007 \\
\hline
\end{tabular}

(table III) did not show a short time, short distance interaction comparable with that in table II but there was an excess of pairs within 30 days and at rather greater distances, ranging from about $1 \mathrm{~km}$ up to $5 \mathrm{~km}$. The slightly more diffuse temporal boundary might be due to the relative uncertainty of the estimated birth dates, and the wider geographical limit to local migration between birth and registration. It is unlikely that the less striking birth interaction could be the indirect source of the registration interaction, although the reverse is possible. Alternatively, the two findings could be secondary to an interaction at an intermediate date; or both could be independent phenomena.

\section{DIAGNOSTIC AND AGE HETEROGENEITIES}

The short time, short distance interaction shown in table II for date and place of registration was disaggregated (1) into the three different diagnostic groups, (2) between boys and girls, and ( 3 ) between different age bands. Interactions were sought within each subgroup, and among pairs spanning the disaggregated groups.

Among the different diagnostic groups (table IV) the effect was concentrated among the lymphatic/unspecified leukaemias. It could not be detected in the other groups, possibly because there were so few short range pairs. Nor could it

Table IV Cumulative spatial-temporal interaction. Registrations disaggregated by diagnostic group

\begin{tabular}{|c|c|c|c|}
\hline & $<0.5 \mathrm{~km},<15 \mathrm{~d}$ & $<0.5 \mathrm{~km},<30 \mathrm{~d}$ & $<0.5 \mathrm{~km},<60 \mathrm{~d}$ \\
\hline $\begin{array}{l}\text { Groups } 1+2+3^{a} \\
\text { Observed }(\mathrm{O}) \\
\text { Expected (E) } \\
\mathrm{O} / \mathrm{E} \\
\mathrm{p}\end{array}$ & $\begin{array}{c}22 \\
12.99 \\
1.69 \\
0.014\end{array}$ & $\begin{array}{c}35 \\
25 \cdot 39 \\
1.38 \\
0.041\end{array}$ & $\begin{array}{c}68 \\
50.01 \\
1.36 \\
0.009\end{array}$ \\
\hline $\begin{array}{l}\text { Group 1 } \\
\text { Observed (O) } \\
\text { Expected (E) } \\
\text { O/E } \\
\mathbf{p}\end{array}$ & $\begin{array}{l}13 \\
6 \cdot 36 \\
2 \cdot 04 \\
0 \cdot 014\end{array}$ & $\begin{array}{l}21 \\
12.30 \\
1.71 \\
0.015\end{array}$ & $\begin{array}{c}36 \\
24 \cdot 29 \\
1.48 \\
0.015\end{array}$ \\
\hline $\begin{array}{l}\text { All other pairs }{ }^{b} \\
\text { Observed (O) } \\
\text { Expected (E) } \\
\text { O/E } \\
\mathbf{p}\end{array}$ & $\begin{array}{l}9 \\
6.63 \\
1.36 \\
\end{array}$ & $\begin{array}{r}14 \\
13.09 \\
1.07 \\
-\end{array}$ & $\begin{array}{r}32 \\
25 \cdot 72 \\
1.24 \\
\end{array}$ \\
\hline
\end{tabular}

All "other" pairs include $2: 2,3: 3,1: 2,1: 3,2: 3$. Group 1 pairs comprise only 1:1. be demonstrated among cross pairs spanning different diagnostic groups.

Space-time clustering was evident both among boys and among girls. Within $0.5 \mathrm{~km}$ and 60 days there were $27 \mathrm{MM}$ pairs against an expected 17.68 $(\mathrm{p}=0.023)$; and there were $16 \mathrm{FF}$ pairs against an expected $8.56(p=0.005)$. Oddly, there was no interaction among the MF cross pairs.

Space-time interaction was initially sought separately in children aged $0-59$ months and in children aged 60 months or more. The $\mathrm{O} / \mathrm{E}$ ratios were greater among the older children than among the younger ones but stronger still, and highly significant, among pairs spanning the chosen age boundary. For example, there were 26 cross group pairs within $0.5 \mathrm{~km}$ and 60 days against an expected $11.96(\mathrm{p}<0.001)$. The data were therefore re-examined in three age bands: 0-3 years, 4-7 years, and 8-14 years. The results are given in table $\mathrm{V}$, confirming that the main strength of the interaction lies in the intermediate age band (4-7 years). Furthermore, diagnostic disaggregation within this age band confirmed that the main interaction related to the lymphatic/ unspecified leukaemias, possibly combined with the lymphomas. In this combined grouping (lymphatic/unspecified leukaemia + lymphoma) in children aged 4-7 years, there were 17 pairs within $1.5 \mathrm{~km}$ and 30 days of each other against an expected $5.93(\mathrm{p}<0.001)$.

REGIONAL HETEROGENEITIES AND POPULATION DENSITIES

Close space-time pairs were located on a map. They showed a strong apparent concentration along a corridor stretching from the conurbations of north west England (Liverpool, Manchester, Lancashire), through the industrial Midlands, towards the south east (London, Dover). This is as might be expected for close spatial pairs, irrespective of their time separations, because high population densities increase their frequencies. Geographical heterogeneities should not in themselves give rise to artefactual spacetime interactions, but they are capable under some circumstances of masking genuine ones. If the critical distance for identifying interaction pairs 
Table V Cumulative temporal-spatial interaction: all diagnoses. Registrations disaggregated by age band.

\begin{tabular}{|c|c|c|c|c|c|c|c|c|}
\hline & & $\begin{array}{r}<0.5 \mathrm{~km}, \\
\quad<15 \mathrm{~d} \\
\end{array}$ & $\begin{array}{r}<0.5 \mathrm{~km} \\
\quad<30 \mathrm{~d}\end{array}$ & $\begin{array}{r}<0.5 \mathrm{~km}, \\
\quad<60 \mathrm{~d}\end{array}$ & $\begin{array}{r}<0.5 \mathrm{~km}, \\
\quad<90 \mathrm{~d}\end{array}$ & $\begin{array}{r}<1.5 \mathrm{~km}, \\
\quad<30 \mathrm{~d}\end{array}$ & $\begin{array}{r}<1.5 \mathrm{~km}, \\
<60 \mathrm{~d}\end{array}$ & $\begin{array}{l}<1.5 \mathrm{~km}, \\
<90 \mathrm{~d}\end{array}$ \\
\hline All ages & $\begin{array}{l}\mathrm{O} \\
\mathrm{E} \\
\mathrm{O} / \mathrm{E} \\
\mathrm{p}\end{array}$ & $\begin{array}{c}22 \\
12.99 \\
1.69 \\
0.014\end{array}$ & $\begin{array}{l}35 \\
25 \cdot 39 \\
1.38 \\
0.041\end{array}$ & $\begin{array}{l}68 \\
50.01 \\
1.36 \\
0.009\end{array}$ & $\begin{array}{c}92 \\
74.74 \\
1.25 \\
0.029\end{array}$ & $\begin{array}{l}153 \\
134 \cdot 20 \\
1 \cdot 14 \\
0.59\end{array}$ & $\begin{array}{c}285 \\
264 \cdot 32 \\
1 \cdot 08 \\
0 \cdot 108\end{array}$ & $\begin{array}{l}422 \\
395 \cdot 06 \\
1 \cdot 07 \\
0 \cdot 093\end{array}$ \\
\hline Band 1: $0-47$ months & $\begin{array}{l}\mathrm{O} \\
\mathrm{E} \\
\mathrm{O} / \mathrm{E} \\
\mathrm{p}\end{array}$ & $\begin{array}{l}4 \\
1 \cdot 94 \\
2 \cdot 06 \\
0 \cdot 132\end{array}$ & $\begin{array}{l}6 \\
3 \cdot 83 \\
1 \cdot 57 \\
0 \cdot 189\end{array}$ & $\begin{array}{l}10 \\
7.57 \\
1.32 \\
0.232\end{array}$ & $\begin{array}{l}12 \\
11 \cdot 30 \\
1.06 \\
0.456\end{array}$ & $\begin{array}{c}19 \\
17 \cdot 16 \\
1 \cdot 11 \\
0.360\end{array}$ & $\begin{array}{c}38 \\
33.94 \\
1 \cdot 12 \\
0.265\end{array}$ & $\begin{array}{l}52 \\
50 \cdot 66 \\
1 \cdot 03 \\
0.444\end{array}$ \\
\hline Band 2: $48-83$ months & $\begin{array}{l}\mathrm{O} \\
\mathrm{E} \\
\mathrm{O} / \mathrm{E} \\
\mathrm{p}\end{array}$ & $\begin{array}{l}2 \\
0 \cdot 78 \\
2 \cdot 57 \\
0 \cdot 184\end{array}$ & $\begin{array}{l}6 \\
1 \cdot 51 \\
3.98 \\
0.005\end{array}$ & $\begin{array}{l}6 \\
2 \cdot 95 \\
2 \cdot 03 \\
0 \cdot 079\end{array}$ & $\begin{array}{l}8 \\
4 \cdot 47 \\
1 \cdot 79 \\
0 \cdot 084\end{array}$ & $\begin{array}{c}19 \\
7.76 \\
2.45 \\
<0.001\end{array}$ & $\begin{array}{l}24 \\
15 \cdot 20 \\
1.58 \\
0.022\end{array}$ & $\begin{array}{l}31 \\
23 \cdot 01 \\
1 \cdot 35 \\
0.064\end{array}$ \\
\hline Band 3: $84-167$ months & $\begin{array}{l}\mathrm{O} \\
\mathrm{E} \\
\mathrm{O} / \mathrm{E} \\
\mathrm{p}\end{array}$ & $\begin{array}{l}3 \\
2 \cdot 00 \\
1.5 \\
0 \cdot 323\end{array}$ & $\begin{array}{l}5 \\
3 \cdot 93 \\
1 \cdot 27 \\
0 \cdot 357\end{array}$ & $\begin{array}{l}12 \\
7.72 \\
1.55 \\
0.093\end{array}$ & $\begin{array}{l}15 \\
11.52 \\
1.30 \\
0.186\end{array}$ & $\begin{array}{c}12 \\
21.20 \\
0.57 \\
0.988\end{array}$ & $\begin{array}{l}33 \\
41 \cdot 66 \\
0.79 \\
0.926\end{array}$ & $\begin{array}{l}51 \\
62 \cdot 16 \\
0 \cdot 82 \\
0 \cdot 934\end{array}$ \\
\hline Age band cross pairs & $\begin{array}{l}\mathrm{O} \\
\mathrm{E} \\
\mathrm{O} / \mathrm{E} \\
\mathrm{p}\end{array}$ & $\begin{array}{l}13 \\
8.27 \\
1.57 \\
0.078\end{array}$ & $\begin{array}{l}18 \\
16 \cdot 12 \\
1 \cdot 12 \\
0.352\end{array}$ & $\begin{array}{l}40 \\
31 \cdot 77 \\
1.26 \\
0.089\end{array}$ & $\begin{array}{l}57 \\
47.45 \\
1.20 \\
0.097\end{array}$ & $\begin{array}{c}103 \\
88.08 \\
1 \cdot 17 \\
0.065\end{array}$ & $\begin{array}{c}190 \\
173.52 \\
1.04 \\
0.114\end{array}$ & $\begin{array}{l}288 \\
259 \cdot 23 \\
1 \cdot 11 \\
0 \cdot 041\end{array}$ \\
\hline
\end{tabular}

$\mathrm{O}=$ observed, $\mathrm{E}=$ expected registrations

were to vary in different density zones-as it might do in the context of an infective modelthen the phenomenon might be blurred out within a dataset containing the pooled cases from different density zones.

The interaction search was therefore repeated for three zones separately: the central corridor, and the two zones on either side. The results are given in table VI. Independent space-time interactions were detected in the central corridor and in the north eastern region, but not in the south west. This may have been due to the smaller number of cases and the sparsity of short range pairs in the south western zone.

This set of results did indeed show some evidence of heterogeneities of critical distance. In the dense central corridor, the most significant interactions were at $0 \cdot 1 \mathrm{~km}$ and 35 days $(\mathrm{O}, \mathrm{E}$, $\mathrm{O} / \mathrm{E}=10,2 \cdot 18,4 \cdot 59 ; \mathrm{p}<0.0001)$ and at $0 \cdot 1 \mathrm{~km}$ and 10 days $(\mathrm{O}, \mathrm{E}, \mathrm{O} / \mathrm{E}=5,0.64,7 \cdot 78 ; \mathrm{p}<0.001)$. In

Table VI Cumulative spatial-temporal distribution of pairs: all diagnoses. Registrations by separate geographical zones

\begin{tabular}{|c|c|c|c|c|c|c|c|}
\hline \multirow{2}{*}{\multicolumn{2}{|c|}{ Time separationn (days) }} & \multicolumn{6}{|c|}{ Distance separation $(\mathrm{km})$} \\
\hline & & \multirow[t]{2}{*}{$0-0 \cdot 1$} & \multirow{2}{*}{$\frac{0-0 \cdot 3}{\text { South }}$} & \multirow{2}{*}{$\frac{0-0.6}{\text { tern zone }}$} & \multirow[t]{2}{*}{$0-1 \cdot 2$} & \multirow[t]{2}{*}{$0-2 \cdot 0$} & \multirow[t]{2}{*}{$0-100 \cdot 0$} \\
\hline & & & & & & & \\
\hline \multirow{2}{*}{$0-15$} & $\mathrm{O}$ & 0 & 2 & 3 & 3 & 5 & 1489 \\
\hline & E & $0 \cdot 20$ & 0.60 & $1 \cdot 72$ & $3 \cdot 78$ & 7.91 & \\
\hline \multirow[t]{2}{*}{$0-30$} & $\mathrm{O}$ & 0 & 3 & 5 & 9 & 21 & 4147 \\
\hline & $\mathrm{E}$ & 0.55 & 1.68 & $4 \cdot 78$ & $10 \cdot 54$ & $22 \cdot 02$ & \\
\hline \multirow[t]{2}{*}{$0-50$} & $\mathrm{O}$ & 0 & 4 & 10 & 17 & 36 & 6947 \\
\hline & E & 0.92 & $2 \cdot 82$ & 8.02 & $17 \cdot 66$ & $36 \cdot 88$ & \\
\hline \multirow[t]{2}{*}{$0-100$} & $\mathrm{O}$ & 0 & 7 & 18 & 38 & 67 & 13715 \\
\hline & $\begin{array}{l}\mathrm{E} \\
\mathrm{O}\end{array}$ & $17^{1 \cdot 82}$ & $5^{5 \cdot 56}$ & $1_{148}^{15 \cdot 82}$ & $\begin{array}{c}34 \cdot 86 \\
326\end{array}$ & $\begin{array}{l}72 \cdot 82 \\
4446\end{array}$ & 128269 \\
\hline $0-1000$ & & & $C e$ & l zone & & & \\
\hline $0-15$ & $\mathrm{O}$ & $5 \dagger$ & $6^{\star}$ & 11 & $\begin{array}{l}31 \\
26 \cdot 48\end{array}$ & $\begin{array}{l}70 \\
63 \cdot 12\end{array}$ & 15581 \\
\hline $0-30$ & $\mathrm{O}$ & $\begin{array}{l}9 \pm \\
1.86\end{array}$ & $\begin{array}{c}11^{\star} \\
6.09\end{array}$ & $\begin{array}{l}22 \\
17.68\end{array}$ & $\begin{array}{l}61 \\
51 \cdot 80\end{array}$ & $\begin{array}{l}135 \\
123.49\end{array}$ & 30482 \\
\hline $0-50$ & $\mathrm{O}$ & $11 \neq$ & 15 & 35 & 99 & 210 & 50431 \\
\hline \multirow{2}{*}{$0-100$} & $\begin{array}{l}\mathrm{E} \\
\mathrm{O}\end{array}$ & $\begin{array}{l}3 \cdot 07 \\
12^{\star}\end{array}$ & $\begin{array}{l}10 \cdot 07 \\
28\end{array}$ & $\begin{array}{l}29 \cdot 25 \\
64\end{array}$ & $\begin{array}{l}85 \cdot 70 \\
174\end{array}$ & $\begin{array}{l}204 \cdot 30 \\
394\end{array}$ & 99892 \\
\hline & $\mathrm{E}$ & 6.08 & 19.95 & 57.93 & $169 \cdot 74$ & $404 \cdot 68$ & \\
\hline \multirow[t]{2}{*}{$0-1000$} & $\mathrm{O}$ & 57 & 187 & 543 & 1591 & 3793 & 936280 \\
\hline & & & North & tern zone & & & \\
\hline \multirow[t]{2}{*}{$0-15$} & $\mathrm{O}$ & 0 & $7 \ddagger$ & $11^{\star}$ & $24^{\star}$ & $45^{\star}$ & 6872 \\
\hline & $\mathrm{E}$ & $0 \cdot 38$ & 1.95 & 5.72 & 15.93 & $34 \cdot 42$ & \\
\hline \multirow[t]{2}{*}{$0-30$} & $\mathrm{O}$ & 2 & $9 \star$ & 14 & 35 & 73 & 13224 \\
\hline & $\mathrm{E}$ & $0 \cdot 72$ & 3.75 & 11.02 & $30 \cdot 65$ & $66 \cdot 23$ & \\
\hline \multirow[t]{2}{*}{$0-50$} & $\bar{O}$ & 2 & $13^{\star}$ & $26^{\star}$ & 58 & 123 & 21686 \\
\hline & $\mathrm{E}$ & $1 \cdot 19$ & $6 \cdot 15$ & 18.07 & $50 \cdot 26$ & $108 \cdot 61$ & \\
\hline \multirow[t]{2}{*}{$0-100$} & $\mathrm{O}$ & 2 & $22 t$ & 39 & 113 & 227 & 42840 \\
\hline & $\mathrm{E}$ & $2 \cdot 34$ & $12 \cdot 14$ & 35.69 & $99 \cdot 29$ & 214.55 & \\
\hline $0-1000$ & $\mathrm{O}$ & 22 & 114 & 335 & 932 & 2014 & 402136 \\
\hline
\end{tabular}

South western zone is defined as $(\mathrm{N}+1 \cdot 2 \mathrm{E})<730 \cdot 0$; North eastern zone is defined as $(\mathrm{N}+1 \cdot 2 \mathrm{E})>860 \cdot 0$

$\mathrm{O}=$ observed, $\mathrm{E}=$ expected number of registrations

$\mathrm{O}=$ observed, $\mathrm{E}=$ expected num
${ }^{\star} \mathrm{p}<0.05,+\mathrm{p}<0.01, \pm \mathrm{p}<0.001$ the north eastern region, the most significant interaction was within $0.3 \mathrm{~km}$ and 25 days $(\mathrm{O}, \mathrm{E}$, $\mathrm{O} / \mathrm{E}=9,3 \cdot 10,2 \cdot 90 ; \mathrm{p}<0 \cdot 01)$.

Standardisation for population density was carried out, as described earlier. The effect of density standardisation was to reallocate some of the short distances in the central corridor and in the north east to rather longer distances, and to do the opposite in the south west. Results for the three separate zones are given in table VII. In the event, these manoeuvres made little difference. There was still evidence of an interaction in the central and north eastern zones, but none in the south western zone.

\section{TRIPLETS}

The analysis of pairs was supplemented by an analysis of all possible triplets, using the technique described above. The results confirmed the presence of space-time clustering in the central and north eastern regions and this time provided some positive evidence in the south western zone as well. The central zone gave significant findings at several levels, for example at 200 days and $0.5 \mathrm{~km}(\mathrm{O}, \mathrm{E}, \mathrm{O} / \mathrm{E}=7,2.78,2.51)$. In the north east there was an excess at a range of $10 \mathrm{~km}$ and 20 days $(\mathrm{O}, \mathrm{E}, \mathrm{O} / \mathrm{E}=137,111 \cdot 13,1 \cdot 23)$. In the south west there was a significant although small proportional excess at $20 \mathrm{~km}$ and 160 days $(\mathrm{O} / \mathrm{E}=1 \cdot 09)$.

\section{Discussion}

The major findings and inferences arising from this study are as follows.

(1) One important finding emerged during the preparation of the file for analysis, namely the near absence of concordant twins. Only one concordant set of twins was detected among 8889 registrations. In a file from which exact dates of birth were excluded, concordant twin pairs who had changed addresses between the two diagnoses might be missed; but a careful search and special enquiry (G J Draper, personal communication) failed to reveal any others. About one in 40 infants in the general population are from multiple pregnancies, leading to an expectation of 223 such infants in this sample, including 75 from monozygotic (MZ) twin pairs. We already knew that $M Z$ twins were often discordant for these dis- 
eases, ${ }^{10}$ although where twins are concordant, they are almost always MZ. However, it is only in a sample such as this that the highly exceptional nature of concordance is apparent. Since only one concordant set of twins was found, and $75 \mathrm{MZ}$ twins were expected from a file of this size, it must represent about 74 discordant $M Z$ pairs. The single concordant pair (both males and both occurring during the first year of life) is no more than might be expected from one of the very rare genetically determined immunological deficiencies predisposing to malignancies.

The lack of concordant MZ twins in this dataset suggests that the major causes of leukaemia and lymphoma impinge at a time later than that corresponding with the division of the ovum to form an $\mathrm{MZ}$ pair. ${ }^{10}$ Furthermore, these environmental causes-as they necessarily are-must operate in a highly stochastic manner, such as to strike the twin of an affected subject at a frequency not much greater than that in the population as a whole.

(2) The second major finding was a highly significant pattern of space-time clustering with respect to dates and times of onset, as reflected in the anniversary dates. This confirms findings in the several previous studies quoted. The interaction occurred at very short ranges, both geographically and in time, for example within boundaries of 30 days and $300-500$ metres. It is extremely unlikely that this could be the result of localised overdiagnosis-say a mistaken allocation of a leukaemia diagnosis to children with glandular fever or whooping cough. Nor was there any evidence of short term temporal "anticipation" of a second local diagnosis within a period of some weeks; this should have produced a secondary medium term temporal deficiency, at the same short range, to match the short term temporal excess. No such deficiency occurred. Finally, the registration date interaction did not appear to be

Table VII Cumulative spatial-temporal distribution of pairs. Registrations by separate geographical zones: standardised distances

\begin{tabular}{|c|c|c|c|c|c|c|c|}
\hline \multirow{2}{*}{\multicolumn{2}{|c|}{ Time separation (days) }} & \multicolumn{6}{|c|}{ Distance separation $(\mathrm{km})$} \\
\hline & & \multirow{2}{*}{$\begin{array}{c}0-0 \cdot 1 \\
1\end{array}$} & \multirow{2}{*}{$\begin{array}{c}0-0 \cdot 3 \\
\begin{array}{c}\text { South } \\
2\end{array}\end{array}$} & $\frac{0-0.6}{\text { tern zone }}$ & \multirow[t]{2}{*}{$0-1 \cdot 2$} & \multirow[t]{2}{*}{$0-2 \cdot 0$} & \multirow{3}{*}{$\frac{0-100 \cdot 0}{2841}$} \\
\hline $0-15$ & & & & $\begin{array}{c}\text { stern zone } \\
2\end{array}$ & & & \\
\hline & $\mathrm{E}$ & 0.48 & 0.98 & $3 \cdot 40$ & 11.09 & $44 \cdot 31$ & \\
\hline $0-30$ & $\mathrm{O}$ & 1 & 4 & 5 & 15 & 75 & 5572 \\
\hline & $\begin{array}{l}\mathrm{E} \\
\mathrm{O}\end{array}$ & 0.55 & 1.68 & $4 \cdot 78$ & $10 \cdot 54$ & $22 \cdot 02$ & \\
\hline $0-50$ & $\mathrm{O}$ & $\begin{array}{l}1.58 \\
1.58\end{array}$ & $\begin{array}{l}4 \\
3.21\end{array}$ & 10 & $\begin{array}{l}27 \\
36.22\end{array}$ & 129 & 9282 \\
\hline $0-100$ & $\mathrm{O}$ & 3 & 6 & 18 & 54 & $\begin{array}{l}268.18 \\
268\end{array}$ & 18238 \\
\hline & $\mathrm{E}$ & $3 \cdot 10$ & $6 \cdot 31$ & 21.83 & $71 \cdot 17$ & $284 \cdot 48$ & 10250 \\
\hline $0-1000$ & $\mathrm{O}$ & 29 & 59 & 204 & 665 & 2658 & 170407 \\
\hline & & & & al zone & & & \\
\hline $0-15$ & $\stackrel{\mathrm{O}}{\mathrm{E}}$ & $\begin{array}{l}5^{\star} \\
1.79\end{array}$ & $\begin{array}{l}8 \\
4.57\end{array}$ & $\begin{array}{l}25 \\
19.06\end{array}$ & $\begin{array}{l}80 \\
70.54\end{array}$ & $\begin{array}{l}354 \\
347.50\end{array}$ & 18812 \\
\hline $0-30$ & $\mathrm{O}$ & $9 \dagger$ & $15^{\star}$ & 46 & 151 & 697 & 36745 \\
\hline & $\mathrm{E}$ & 3.49 & 8.93 & $37 \cdot 24$ & 137.79 & 678.75 & \\
\hline $0-50$ & ${ }_{\mathrm{E}}^{\mathrm{O}}$ & $11^{\star \star} \cdot 78$ & 19 & 70 & 236 & 1150 & 60849 \\
\hline $0-100$ & O & $\begin{array}{c}5 \cdot 18 \\
18^{\star}\end{array}$ & $\begin{array}{l}14.79 \\
30\end{array}$ & $61 \cdot 66$ & 228. & $1124 \cdot 00$ & 120300 \\
\hline & E & $11 \cdot 42$ & $29 \cdot 25$ & 121.91 & $\begin{array}{l}465 \\
451 \cdot 12\end{array}$ & $\begin{array}{l}2237 \\
2222 \cdot 18\end{array}$ & 120300 \\
\hline $0-1000$ & 0 & 107 & 274 & 1142 & 4226 & 20817 & 1126948 \\
\hline $0-15$ & $\mathrm{O}$ & $4^{\star}$ & $\begin{array}{l}\text { North } \\
10 \dagger\end{array}$ & $\begin{array}{l}\text { stern zone } \\
24 t\end{array}$ & & & 9970 \\
\hline & E & 1.25 & 3.52 & $13 \cdot 46$ & $45 \cdot 40$ & $188 \cdot 89$ & \\
\hline $0-30$ & $\mathrm{O}$ & $6^{\star}$ & $12^{\star}$ & 33 & 98 & 389 & 19308 \\
\hline $0-50$ & ồ & 9 & $\begin{array}{l}0.03 \\
16^{\star}\end{array}$ & $\begin{array}{l}26 \cdot 0 \\
56^{\star}\end{array}$ & $\begin{array}{l}87.92 \\
155\end{array}$ & $\begin{array}{l}365 \cdot 80 \\
619\end{array}$ & 31745 \\
\hline & $\mathrm{E}$ & 3.97 & $11 \cdot 22$ & $42 \cdot 85$ & 144.56 & 601 & 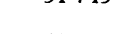 \\
\hline $0-100$ & O & $15^{\star}$ & 27 & 96 & 298 & 1227 & 62911 \\
\hline $0-1000$ & o & 74 & 209 & 798 & $\begin{array}{r}2600 \\
268\end{array}$ & 11200 & 591170 \\
\hline
\end{tabular}

$\mathrm{O}=$ observed, $\mathrm{E}=$ expected numbers of registration ${ }^{*} \mathrm{p}<0.05, \mathrm{tp}<0.01$ secondary to a birth date interaction. There may be an independent tendency for dates and places of birth to cluster; or, possibly, both findings may be secondary to a clustering tendency at some intermediate date. We shall examine this further in a later report.

Within the constraints imposed by small numbers, the space-time clusters seemed to be concentrated in children between the ages of 4 and 7 years, and (probably) among those suffering from lymphatic/unspecified leukaemias, or lymphomas. Boys and girls were involved equally. Children under 4 years of age and over 8 years of age and those suffering from myeloid leukaemias were not obviously involved.

(3) The space-time interactions themselves showed geographical heterogeneities. They were clearly detectable in a very highly populated central corridor of Great Britain, stretching from the north west conurbations of Lancashire, Manchester, and Liverpool, through the Midlands towards the south east and London, and in the north eastern region of England, together with Scotland, but not in the more dispersed populations of Wales and the south west of England. The examination was repeated using density standardisation but the conclusion was the same. An examination of triplets introduced weak evidence of an interaction in the south west, but did not fundamentally alter the picture. The critical distance for detecting interactions was less in zones of high population density; and the existence of a sufficient number of close geographical pairs, itself depending upon a high density of population, appeared to be a prerequisite for demonstrating space-time interactions. It is however difficult to distinguish between a biological necessity and a simple statistical necessity.

(4) This demonstration of space-time clustering raises several additional and important questions. The first is whether the space-time clusters are freely located in the population: or whether they are superimposed upon, and interact with, a consistent underlying geographical heterogeneity of risk. To answer this question it will be necessary first to see whether geographical heterogeneities exist, and whether any spatial clusters are characterised by the same short ranges as those observed in the space-time clusters. The observed geographical scale dependency of the space-time clusters provides a firm prior hypothesis against which to test the characteristics of the geographical distributions. However, the question of time independent geographical variation was not within the primary objectives of the present analysis, and its detailed examination is deferred to a companion report.

(5) It is extremely difficult to construct a biological model capable of generating space-time clustering within such short distances and such short times, yet which scarcely ever repeats within the same family and which almost never occurs in both members of a twin pair. This is equally true for radiation, for toxic exposures, and for person to person transmissions of infection. Environmental exposures leading to a primary oncogenic mutation, and simultaneously affecting a local population-such as transient and local obstetric radiology fashions, or group overdoses from faulty equipment, or parental occupational 
exposure to radiation or to toxic materials, or even cosmic ray showers-are unlikely to initiate disease natural histories of such uniformity as to achieve paired registrations on dates so narrowly separated. This suggests that there must be a pair shared disease-promoting event quite close to the date of registration; and therefore probably precipitating the presentation of disease already present.

One possibility would be an infective agent which provoked haematological examinations. The space-time clusters could then reflect the spread of infectious mononucleosis, or asthma microepidemics, or swollen lymph nodes from respiratory infection. This might lead to the clustered discovery of leukaemias which had not yet presented clinically. We shall reconsider these possibilities when we have examined the question of geographical clustering, independent of time.

We are grateful to Dr G J Draper and the Childhood Cancer Research Group for providing the data on which these analyses are based. Thanks are also due to the cancer registries and the UK Children's Cancer Study Group who originally provided the cancer registrations.
1 Gilman EA, Knox EG. Temporal-spatial distribution of childhood leukaemias and non-Hodgkin lymphomas in Great Britain. In: Draper G, ed. The geographical epidem iology of childhood leukaemia and non-Hodgkin lymphomas in Great Britain, 1966-83. (Studies on Medical Population Subjects, No 53.) London: OPCS, 1991.

2 Knox EG. Epidemiology of childhood leukaemia in Northumberland and Durham. Br F Prev Soc Med 1964 18: $17-24$.

3 Spence-Meighan MS, Knox EG. Leukaemia in childhood. Epidemiology in Oregon. Cancer 1965; 18: 811-4.

4 Knox EG. Detection of low intensity epidemicity: application to cleft lip and palate. Br $\mathcal{F}$ Prev Soc Med 1963; 17: 121-7.

5 Gunz FW and Spears GFS. Distribution of acute leukaemia in time and space. Studies in New Zealand. BMF 1968; iv: 604-8.

6 Smith PG. Spatial and temporal clustering. In: Schotterfeld $\mathrm{D}$, Fraumeni JF, eds. Cancer epidemiology and prevention. Dhiladelphia: WB Saunders, 1982: chapter 21.

7 Stiller CA, O'Connor CM. Vincent TJ, Draper GJ. The Stiller CA, O'Connor CM, Vincent TJ, Draper GJ. The
National Registry of Childhood Tumours and the leukaemia/lymphoma data for 1966-83. In: Draper G, ed. The geographical epidemiology of childhood leukaemia and non-Hodgkin lymphomas in Great Britain, 1966-83. (Studies on Medical and Population Subjects, No 53. . London: OPCS, 1991.

8 Wilson PR, Elliot DJ. An evaluation of the Postcode Address File as a sampling frame and its use within OPCS. $\mathcal{F} R$ Stat Soc $A$ 1987; 150: 230-40.

9 Knox EG, Lancashire RJ. Epidemiology of congenital malformations. London: HMSO, 1991.

10 Knox EG, Marshall T, Barling R. Leukaemia and childhood cancer in twins. $\mathcal{F}$ Epidemiol Community Health 1984; 38 cancer $12-16$. 